\title{
Ethmoidal dural arteriovenous fistulas: endovascular transvenous embolization technique
}

\author{
Jorge A Roa (D) ,' Guilherme Dabus, ${ }^{2}$ Sudeepta Dandapat, ${ }^{3}$ David Hasan, ${ }^{4}$ \\ Edgar A Samaniego (iD ${ }^{5}$
}

${ }^{1}$ Neurology and Neurosurgery, University of lowa Hospitals and Clinics, lowa City, lowa, USA Interventional Neuroradiology and Neuroendovascularl Surgery, Miami Cardiac \& Vascular Institute and Baptist Neuroscience Center, Miami, Florida, USA

${ }^{3}$ Neurology, University of lowa Roy J and Lucille A Carver College of Medicine, lowa City, Iowa, USA

${ }^{4}$ Neurosurgery, University of lowa Hospitals and Clinics, lowa City, lowa, USA

${ }^{5}$ Neurology, Neurosurgery and Radiology, University of lowa Hospitals and Clinics, lowa City, Iowa, USA

Correspondence to Dr Edgar A Samaniego, Neurology, Neurosurgery and Radiology, University of lowa Hospitals and Clinics, lowa City, IA 52246, USA; edgarsama@ gmail.com

Received 5 December 2019 Revised 7 January 2020 Accepted 9 January 2020 Published Online First 24 January 2020

\section{Check for updates}

(c) Author(s) (or their employer(s)) 2020. No commercial re-use. See rights and permissions. Published by BMJ.

To cite: Roa JA, Dabus G,

Dandapat $\mathrm{S}$, et al.

$J$ Neurolntervent Surg

2020;12:610.

\section{ABSTRACT}

Ethmoidal dural arteriovenous fistulas (dAVFs) are rare, accounting for $1-1.5 \%$ of all intracranial malformations. ${ }^{1}$ However, they may have angiographic features that increase the risk of rupture: cortical venous drainage, venous ectasia, venous stenosis and high arterial flow. If the dAVF has these angiographic features, treatment may be indicated regardless of the clinical presentation. ${ }^{2-4}$ In this neurosurgical endovascular video 1 , we present two patients with high-flow ethmoidal dAVFs treated via transvenous endovascular approaches. The first case was successfully embolized without complications, whereas the second case was complicated with intraoperative rupture of a tortuous cortical draining vein. The transvenous endovascular approach may be a useful tool in treating these lesions; however, access and tortuosity of structures proximal to the fistula point have to be thoroughly assessed. We review the natural history and angioarchitecture of these lesions. ${ }^{5-7}$ Important tips and bailout maneuvers for treatment of complex ethmoidal dAVFs in eloquent locations are also presented.

\section{VIDEO HIGHLIGHTS}

- Introduction: 00:04

- Angio-architecture: 00:18

- Natural history: 01:23

- Case 1:

- Clinical presentation: 01:54

- Jugular puncture: 02:39

- Transvenous access: 03:30

- Successful endovascular embolization: 04:30

- Post-embolization angiography: 04:56

- Case 2:

- Clinical presentation: 05:16

- Transvenous access: 06:19

- Draining vein rupture: 06:38

- Hemicraniectomy + subdural hematoma evacuation + microsurgicaldAVF excision: $07: 14$

- Follow-up angiography: 07:26

- Summary/highlights: 07:39

- References: 08:20

Twitter Jorge A Roa @jorge_roa93

Contributors EAS and JAR: manuscript and technical video

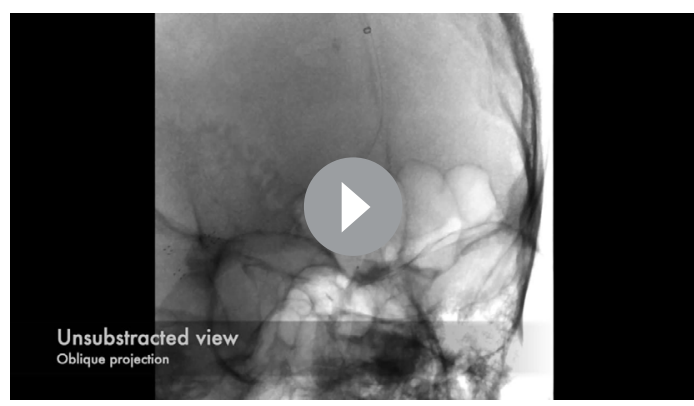

Video 1

preparation, guarantors of the study; GD, SD and DMH: critical revision of contents.

Funding The authors have not declared a specific grant for this research from any funding agency in the public, commercial or not-for-profit sectors.

Competing interests GD is a consultant for Medtronic, Microvention, Penumbra, and Cerenovus. EAS is a consultant for Microvention, Medtronic, and Shape Medical.

Patient consent for publication Obtained

Provenance and peer review Not commissioned; externally peer reviewed.

\section{ORCID iDs}

Jorge A Roa http://orcid.org/0000-0003-4987-8853

Edgar A Samaniego http://orcid.org/0000-0003-2764-2268

\section{REFERENCES}

1 Giannopoulos S, Texakalidis P, Mohammad Alkhataybeh RA, et al. Treatment of ethmoidal dural arteriovenous fistulas: a meta-analysis comparing endovascular versus surgical treatment. World Neurosurg 2019;128:593-9.

2 Defreyne L, Vanlangenhove P, Vandekerckhove T, et al. Transvenous embolization of a dural arteriovenous fistula of the anterior cranial fossa: preliminary results. AJNR Am J Neuroradiol 2000;21:761-5.

3 Samaniego EA, Fisher M, Hasan D, et al. Embolization of palpebral and orbito-frontal fistulas: technical and anatomical considerations in treating high-flow superficial skin lesions with liquid embolics. J Neurointerv Surg 2018;10:240-4.

4 Robert T, Blanc R, Smajda S, et al. Endovascular treatment of cribriform plate dural arteriovenous fistulas: technical difficulties and complications avoidance. J Neurointerv Surg 2016;8:954-8.

5 Spiotta AM, Hawk H, Kellogg RT, et al. Transfemoral venous approach for Onyx embolization of anterior fossa dural arteriovenous fistulae. $J$ Neurointerv Surg 2014;6:195-9.

6 Inoue A, Tagawa M, Kumon Y, et al. Ethmoidal dural arteriovenous fistula with unusual drainage route treated by transarterial embolization. J Neurointerv Surg 2015;7:e15.

7 Lekkhong E, Pongpech S, Ter Brugge K, et al. Transvenous embolization of intracranial dural arteriovenous shunts through occluded venous segments: experience in 51 patients. AJNR Am J Neuroradiol 2011;32:1738-44. 